\title{
AZ EURÓPAI UNIÓS VÉDJEGY (EUTM) KIZÁRÓ LAJSTROMOZÁSI KRITÉRIUMAI MÓDOSULÁSÁNAK HATÁSA A VÁLLALKOZÁSOK VÉDJEGYVÁLASZTÁSÁRA
}

\author{
The Impact of Changes of the Absolute Grounds in EUTM \\ Registration on the Trademark Choices of Businesses
}

\section{Vigh Beáta ${ }^{1}$}

\begin{abstract}
Absztrakt: Az uniós egységesített védjegyrendszer az Európai Unió verseny- és innovációpolitikájának fontos részét képezi, amely egyszerre jelent hatékony jogvédelmi eszközt és kihívást. Az elmúlt évek európai bírósági joggyakorlata rámutatott, hogy rugalmas védjegylajstromozási kritériumok szükségesek, ugyanis a technológiai fejlődés és a digitalizáció következtében új védjegytípusok, új megjelenítési módok jelentek meg, amelyek kizárása a lajstromozási eljárásból a korábbi szigorúbb formai követelmények miatt szükségtelenül szegényebbé tenné a versenyszférát és megfosztaná a vállalkozásokat az újszerű, innovatív megjelölések használatától. A védjegyreform számos hasznos, régóta várt, előremutató változtatást vezetett be a lajstromozási eljárásba mind az anyagi jog, mind az eljárás és az adminisztráció szempontjából, amelyeknek kiindulópontja a védjegy fogalmának megújított meghatározása. A módosításokat több kritika is éri, hiszen a rugalmasabb jogszabályi keretek folyamatosan értelmezési kihívások elé állítják a védjegybejelentést tevő feleket, az Európai Unió Szellemi Tulajdoni Hivatalát, valamint az Európai Bíróságot, amely esetrôl esetre újra értelmezi és alkalmazza a módosult feltétlen kizáró jellegü kritériumokat.
\end{abstract}

Kulcsszavak: európai uniós védjegy, védjegyreform, nem hagyományos védjegy, kizáró lajstromozási kritérium, vállalkozás

1 A szerző a Debreceni Egyetem Marton Géza Doktori Iskola hallgatója, ügyvéd és szabadalmi ügyvivő Romániában. E-mail címe: beata.adam@gmail.com

A szerző további munkásságát lásd a Magyar Tudományos Művek Tára oldalán: https: $/ / \mathrm{m} 2 . \mathrm{mtmt}$. hu $/$ gui $2 /$ ?type $=$ authors\&mode $=$ browse\&sel $=10072837 \& v i e w=$ simpleLi $\underline{s t}$ 
Abstract: The unified European trademark registration system is an important part of the European Union's competition and innovation policy, representing both an effective legal protection tool and a challenge. In the last years, the European Court's case law pointed out to the fact that flexible trademark registration criteria were needed because new trademark types, new forms of representation appeared due to the technological and digital development. The exclusion of these new branding methods from the registration process, based on the formerly narrow criteria, would unnecessary impoverish the field of competition and deprive the companies of using new, innovative forms of marks. The trademark reform introduced many innovative changes in the trademark registration system considering the substantive law, litigations and administrative process. The starting point of the reform is the modified, renewed definition of the trademark. The modifications are also subject of many critical opinions, as the flexible legal framework continuously represents an interpretive challenge for the solicitants, the European Intellectual Property Office and the European Court. The latter reinterprets and applies the modified absolute exclusive registration grounds on a case-by-case basis.

Keywords: european trademark (EUTM), non-traditional trademark, absolute grounds of registration, business

\section{BEVEZETÉS}

Még a kilencvenes években a magyarországi szakirodalom a következőképpen nyilatkozott a márkaépítésről, a védjegy lajstromozása iránti igényről: "Az államilag vizsgált, kizárólagos jogot biztositó és szinte számtalan variánsban felhasználható megjelölés, forma iránt világszerte megnött az igény. Jelenleg a világon több tínillió a lajstromozott védjegyek száma”."

$\mathrm{Ez}$ a trend azóta sem változott, és különösen igaz ez az uniós védjegyek esetében, amelyek nagy előnye a vállalkozások számára, hogy a védjegyként jogi oltalom alá helyezett megjelölés egyszerre, azonos időponttól kizárólagos jogokat biztosít a védjegy tulajdonosának a védjegy felett az összes uniós tagállamban. 1996 óta szinte folyamatosan növekszik az uniós védjegybejegyzési kérelmek száma. 2002-ben volt megfigyelhető

2 TATTAY, 1995. 53.o. 
egy enyhe csökkenés, viszont 2003-ban a kelet-közép európai országok várható EU-csatlakozás reményében megugrott a védjegykérelmek száma, majd egy újabb 7\%-os visszaesés volt tapasztalható a 2008-2009-es években a gazdasági válság miatt. ${ }^{3}$ Azóta szinte töretlenül növekszik a kérelmek száma minden évben, kisebb megtorpanás 2016-ban volt tapasztalható a védjegyreform bevezetése előtt, az 1001/2017-es Rendelet hatályba lépéstől kezdődően viszont folyamatos emelkedésben van az európai uniós védjegybejegyzési kérelmek száma. ${ }^{4}$ 2016-ban az Európai Unió Szellemi Tulajdonjogi Hivatalához 135.377 európai uniós védjegy lajstromozási kérelmet nyújtottak be, 2017-ben 146.443-at, 2018-ban pedig 152.494 -et. ${ }^{5}$ A különbség ugyanakkor az, hogy míg a kilencvenes években egy céget megjelölő egyetlen színes, ábrás védjegy jól alkalmazható volt ${ }^{6}$ a kereskedelmi tevékenység bármely területén, ma már a digitalizáció és az innováció sokféle új védjegy-kategória bevezetését tette szükségessé. A gazdasági és technológiai környezet változása indokolttá tette az uniós védjegyrendszert szabályozó jogszabályok módosítását. A jogalkotó célja az volt, hogy az Európa 2020 Stratégiához $^{7}$ és az Innovatív Európa Programhoz ${ }^{8}$ alkalmazkodva egy újszerú és rugalmas jogszabálykeretet dolgozzon ki az európai uniós védjegyek lajstromozására. ${ }^{9}$ Kérdés azonban, hogy az 1001/2017 Rendelet ${ }^{10}$ módosításai megfelelnek-e a jogbiztonságra vonatkozó elveknek és találkoznak-e a vállalkozók igényeivel. A rendelet rugalmas előírásokat tartalmaz a védjegy definíciójára és a lajstromozási kritériumokra vonatkozóan, ugyanakkor számos kihívás elé állítja az Európai Unió Szellemi Tulajdoni Hivatalát és az Európai Bíróságot, mivel sem a Hivatal, sem a vállalkozók nem rendelkeznek minden konkrét esetben a megfelelő technológiai megoldásokkal a védjegyek lajstromozáshoz

\footnotetext{
${ }^{3}$ EUIPO FACT AND FIGURES REPORT 2016, 2017.

${ }^{4}$ Uo.

${ }^{5}$ EUIPO ANNUAL REPORT, 2018. 4.o.

${ }^{6}$ TATTAY, 1995. 54.o.

7 EURÓPA 2020 STRATÉGIA, 2010.

${ }^{8}$ HORIZON 2020 RÖVID BEMUTATÁsA, 2014.

${ }^{9}$ Az Európa 2020 Stratégia a szellemi alkotásokat érintő jogszabályokkal kapcsolatosan azt a célt tűzte ki a piaci verseny elősegítése és a szellemi alkotások védelmének egységesítése érdekében elsősorban, hogy kialakuljon a szellemi tulajdonjogok egységes piaca. Ennek fontos lépése a jogalkotás terén az európai szabadalom kidolgozása, az Európai Szabadalmi Bíróság felállítása. Az egységes szellemi tulajdonjogok piacának kialakításához hozzá tartozik az egységes védjegyrendszer hatékonyabbá alakítása.

10 Az Európai Parlament És A TANÁcs (EU) 2017/1001 Rendelete, 2017.
} 
szükséges megjelenítésére vonatkozóan. A lajstromozási kritériumok alkalmazásához sok esetben az Európai Bíróság joggyakorlatától várják a választ mind a vállalkozók, mind a Hivatal. Jelen tanulmány azt vizsgálja, hogy létezik-e összefüggés a védjegyreform által bevezetett módosítások és a vállalkozások márkaépítési irányai között. Arra a kérdésre is keresi a választ, hogy a vállalkozások az abszolút kizáró lajstromozási kritériumok rugalmasabbá válására úgy tekintenek, mint lehetôség új eszközök alkalmazására a kereskedelmi céljaik megvalósításához, vagy inkább akadályként, mivel ezáltal kevésbé kiszámítható vált a védjegylajstromozásra irányuló eljárás sikere.

\section{AlKalmazot'T KUTATÁSI MÓDSZEREK}

Az ok-okozati összefüggések megismerésére a továbbiakban a választott kutatási módszer a tartalomelemzés, az összehasonlító elemzés, illetve a meglévő statisztikák elemzése, mint adatelemző kutatási módszerek, amelyek arra hivatottak, hogy összefüggéseket keressenek a megfigyelések között. ${ }^{11}$

A meglévő statisztikák használatának a jelen dolgozatban az a célja, hogy kimutassa, miszerint a vállalatok milyen mértékben élnek az új védjegykategóriák használatának lehetőségével, ezek közül melyeket használják inkább és mit részesítenek előnyben az oltalom alá helyezési kérelmek során: a korábban is használat hagyományos védjegy-kategóriákat, mint a szóvédjegy, az ábrás védjegy vagy inkább a kreatívabb új védjegykategóriákat, mint a hologram, hang, szín, színkombináció stb.

A kutatás az empirikus kutatás módszerét is alkalmazta a 2016. január 1. és 2020. január 1. közötti időszakra vonatkozóan, hogy tanulmányozza, létezik-e összefüggés a védjegy lajstromozására vonatkozó jogszabályi változások és a különböző típusú védjegyekre vonatkozó benyújtott kérelmek között. A kvantitatív elemzés során pedig arra kerestük a választ, hogy van-e összefüggés a védjegyreform bevezetése és a nem hagyományos védjegyekre vonatkozó bejelentések száma között, vagyis a védjegyreform hatással van-e a vállalkozások védjegy-kategóriát érintô opcióira. A mintavétel alapja a védjegybejelentés, a hagyományos és nem hagyományos kategóriájú védjegyek, illetve külön - külön a védjegybejelentések számának vizsgálata évenkénti lebontásban az adott vizsgálati időszakban.

11 BABBIE, 2003.28.o. 


\section{AZ UNIÓS VÉDJEGY ÉS A VÉDJEGYREFORM}

A szellemi alkotások joga, és ezen belül az Európai Unió egységesített védjegyrendszere, az uniós védjegyekre vonatkozó szabályozás az Európai Unió verseny- és innovációpolitikájának fontos részét képezi. A védjegy az Európai Unióban a termékek és szolgáltatások azonosítását, egymástól való megkülönböztetését, a fogyasztók informálását segíti, amely a marketing minden területén, számtalan kivitelezési formában alkalmazható (szó, szlogen, ábra, hang, szín, színösszetétel, térbeli, csomagolás, multimédia védjegy, stb.), használható megjelölés. ${ }^{12}$ Valamennyi uniós tagállamban hatályos, így az európai integráció és az európai uniós verseny fontos alapkövét képezi a vállalkozások számára. Ezenkívül természetesen léteznek más nemzetközi védjegylajstromozási rendszerek is, mint a Madridi Megállapodás rendszere ${ }^{13}$ és a Madridi Protokoll rendszere ${ }^{14}$, amelyeknek uniós tagállamok is részesei.

Az egységes, közösségi védjegyrendszert létrehozó 40/94/EK tanácsi rendelet, más néven a Közösségi Védjegyrendelet 1993 végén született $\operatorname{meg}^{15}$. Korábban, ez európai közösségi politika alakítása során, amelynek a vezérelve az áruk, személyek, tőke szabad mozgása volt, a szellemi alkotások védelmének közösségi jogszabályainak megalkotása sokáig nem látszott szükségesnek. ${ }^{16} \mathrm{Az}$ áttörést egy szerzői jogi ügyben született európai bírósági itélet hozta (a Deutsche Grammophon GmbH v. Metro-SB vs. Grossmarkte GmbH, 78/70. sz. ügyben, 1971. június 8.), ahol a bíróság különbséget tett a szellemi tulajdonjog fennállása és gyakorlása közt, a gyakorlást ismerve el a szabad piaci mozgás egyetlen lehetséges korlátjaként, később pedig hasonló ítéletet hozott az első védjegyügyek egyikében, a C-119/75. sz., Société Terrapin (Overseas) Ltd kontra Société Terranova Industrie CA Kapferer \& Co ügyben 1976 -ban. ${ }^{17}$

Az egységes közösségi szabályozás kidolgozását megelőzte a 89/104 Irányelv ${ }^{18}$ elfogadása a tagállamok védjegyekre vonatkozó jogszabályainak

\footnotetext{
12 TATTAY, 2017. 570.o.

13 MAdRIDI MEgÁlLAPODÁs, 1979.

14 MADRIDI JEGYZŐKÖNYV, 2017.

15 TATTAY, 2017. 85.O.

16 SZALAI, 2015. 67.o.

${ }^{17}$ UO. 68.o.

18 A TANÁCS ELSŐ IRÁNYELVE A VÉDJEGYEKRE VONATKOZÓ TAGÁLLAMI SZABÁLYOK KÖZELÍTÉSÉRŐL, 1988.
} 
közelítése céljából, amely rendelkezik a védjegyoltalom alá helyezhető megjelölésekről is. Annak ellenére, hogy világos volt, az egységes közösségi védjegy hatékony eszköze lehet az egységes piac versenye szabályozásának, a közösségi védjegyre vonatkozó szabályok elfogadása elhúzódott. Ennek oka többek között a hivatalos nyelvre vonatkozó politikai vitára vezethetőek vissza, és arra, hogy nem sikerült megállapodni abban, hogy az újonnan felállítandó Belső Piaci Harmonizációs Hivatal (a továbbiakban rövidítve: OHIM), azaz a „közösségi védjegyhivatal” melyik tagállamban múködjön. ${ }^{19}$

1994-ben hozták létre, és 1996-ban kezdte meg múködését a Belső Piac Harmonizációs Hivatala, a védjegy-és formatervezési minta hivatala, amelyet ma Európai Unió Szellemi Tulajdoni Hivatalának (a továbbiakban: EUIPO) neveznek.

A jogterületet továbbra is a teljes harmonizáció hiánya jellemzi, ami megnehezíti a védjegy fogalmának értelmezését, különösen, hogy az védjegytípusonként eltérô. Például a vizuális védjegyek kategóriáján belül is különböző jelentéssel bír a védjegy megjelenítése, ha egy pozíció védjegyről (T-3/15 - K-Swiss v OHIM ${ }^{20}$ ), hologramról (sz. 01799340121), vagy térbeli védjegyről (T-411/14 - Coca-Cola vs. OHIM ${ }^{22}$, C-353/03 - Nestléé beszélünk és értelmezési kérdéseket vet fel, hogy mitől bír megkülönböztető jelleggel egy szín (sz. 003286614 ${ }^{24}, 002087005^{25}$ ) és védjegyként lajstromozható, más szín pedig nem (T - 143/14 ${ }^{26}$, C-433/17 P - Enercon vs EUIPO $^{27}$ ). Éppen ezért az Európai Bíróság joggyakorlatának kiemelkedő szerepe van a jogfejlesztés szempontjából: ítéleteivel esetről esetre folyamatosan formálja azt és eközben új értelmezési kihívásokra világít rá.

Az elmúlt évek európai bírósági joggyakorlata abba az irányba mutatott, hogy a korábbi, közösségi védjegyre vonatkozó abszolút lajstromozási kritériumokon változtatni szükséges, ugyanis a technológiai fejlődés és a digitalizáció következtében új védjegytípusok, új megjelenítési módok jelentek meg, amelyek kizárása a lajstromozási eljárásból a korábbi szigorúbb formai követelmények miatt szükségtelenül szegényebbé tenné a

\footnotetext{
${ }^{19}$ SZALAI, 2015.70.o.

20 T-3/15 - K-SwISS V OHIM, 2015.

${ }^{21}$ Forrás: https://euipo.europa.eu/eSearch/\#details/trademarks/017993401

22 T-411/14 - COCA-COLA VS. OHIM, 2016.

${ }^{23}$ C-353/03 - NeSTLÉ, 2005.

${ }^{24}$ Forrás: https://euipo.europa.eu/eSearch/\#details/trademarks/003286614

${ }^{25}$ Forrás: https://euipo.europa.eu/eSearch/\#details/trademarks/002087005

$26 \mathrm{~T}-143 / 14$ - EE v OHIM, 2015.

${ }^{27}$ C-433/17 P - ENERCON VS EUIPO, 2018.
} 
versenyszférát és megfosztaná a vállalkozásokat újszerü, innovatív megjelölések azonosító, reklámcélú használatától. A Sieckmann-ügyben ${ }^{28}$ az előzetes döntéshozatali eljárásban, amely egy illat védjegy bejegyzésére vonatkozott, az Európai Bíróság kiemelte, hogy a védjegy megjelenítése akkor felel meg a grafikai ábrázolhatóság követelményének, ha az világos, pontos, önálló, könnyen hozzáférhetô, érthető, tartós és tárgyszerű. A Shield Mark-ügy előzetes döntéshozatali eljárásában hozott döntésben rámutatott, hogy a hangvédjegyek esetében nemcsak a hangok lekottázása, hanem annak az ütemezést, szüneteket, zenei hangokat stb. is tartalmaznia kell ahhoz, hogy ne csak egy grafikai jel legyen. ${ }^{29}$ A Heidelberger bejelentéssel kapcsolatosan pedig megállapította az előzetes döntéshozatali eljárásban, hogy színösszetétel jogi oltalom alá helyezéséhez arra van szükség, hogy a színek olyan előzetesen elhatározott módszer szerint legyenek rendezve, amely előre meghatározott és egységes módon rögzíti a szóban forgó színek egymáshoz való kapcsolatát a megjelölésben. ${ }^{30}$

Kiemelendő, hogy a grafikai ábrázolhatóság kizáró követelménye volt a védjegylajstromozás joggyakorlatának a védjegyreform előtt. A grafikai ábrázolhatóság a lajstromozással és védjegyhasználattal összefüggő jogbiztonság egyik sarokköve volt a védjegyreform előtt, hiszen maga a védjegyjog történeti síkon oda vezethető vissza, hogy a fogyasztó vizuálisan érzékeli a megjelölést, ez rögzül a tudatában, és ennek a következtében a lajstromozott védjegynek is híven kell tükröznie a fogyasztó által érzékelt megjelölést, a megkülönböztető jelleg igazolása és a jogbiztonság szavatolása érdekében. ${ }^{31}$ Ugyanakkor éppen egy ilyen dinamikusan, az innováció hatására gyorsan fejlődő és alakuló jogterületen mint a szellemi tulajdonjog és azon belül is, a védjegyjog, nem zárható ki, sőt kimutatható, hogy időben megváltoznak a jogbiztonság követelményei, és ennek következtében egy olyan fontos lajstromozási kritérium is, mint a grafikai ábrázolhatóság elveszítheti kizáró jellegét, helyet adva rugalmasabb szabályozásnak és ezáltal az új típusú védjegyek megjelenésének, mint a hang, szín, ízvédjegyek.

Mindezek idővel indokolttá tették a joganyag felülvizsgálatát. A közösségi védjegyrendszert elsőként a 207/2009 Rendelet aktualizálta ${ }^{32}$,

\footnotetext{
${ }^{28}$ C-273/00 - SIECKMANN, 2002.

${ }^{29}$ C-283/01 - SHIELD MARK, 2003.

30 C-49/02 - Heidelberger BAUCHEMIE, 2004.

${ }^{31}$ KOVÁTs, 2017. 37-91 o.

32 A TANÁCS 207/2009/EK RENDELETE, 2009.
} 
majd a 2424/2015 Rendelet megváltoztatta a közösségi védjegyre vonatkozó fogalomhasználatot ${ }^{33}$, végül a védjegyreform folyamatát a 1001/2017 Rendelet $^{34}$ teljesítette ki, amely az egységesített uniós védjegyrendszer hatékony és rugalmas szabályozására törekszik.

A védjegyreform számos hasznos, régóta várt, előremutató változtatást vezetett be a lajstromozási eljárásba mind az anyagi jog, mind az eljárás és az adminisztráció szempontjából, amelyeknek kiindulópontja a védjegy fogalmának megújított meghatározása. A jogalkotó eltörölte a grafikai ábrázolhatóság kizárólagos követelményét a védjegy lajstromozásának kizáró jellegű kritériumai közül, és megjelentek olyan új védjegy-kategóriák mint a multimédia, és olyanok, amelyek eddig nem külön kategóriaként szerepeltek mint a pozícióvédjegy, mintavédjegy, hologram, mozgásvédjegy. Ezek megjelenítésének szabályait a Bizottság 626/2018 végrehajtási Rendelet 3. cikke tartalmazza ${ }^{35}$, amely szerint például a multimédia védjegyet audiovizuális fájl segítségével lehet megjeleníteni, a hologramot video fájl segítségével, vagy bemutatott álló képekből álló sorozat segítségével, de arra is teret adott a jogszabály 3. cikk, 4. bekezdése, ha „a védjegy a (3) bekezdésben felsorolt típusok egyikébe sem tartozik, a megjelenítésnek meg kell felelnie az (1) bekezdésben meghatározott előírásoknak, és leírás csatolható hozzá".

A védjegy meghatározása a védjegyreform során időrendben az alábbiakban említett jogszabályok szerint módosult.

A tanács 207/2009 (EU)Rendelete, 2009 február 26-i dátummal, a következőképpen határozta meg a közösségi védjegy fogalmát a 4. cikkben: „Közösségi védjegyoltalom tárgya lehet minden grafikailag ábrázolható megjelölés, így különösen szó - beleértve a személyneveket -, ábra, kép, alakzat, betú, szám, továbbá az áru vagy a csomagolás formája, ha e megjelölés alkalmas arra, hogy valamely vállalkozás áruit vagy szolgáltatásait megkülönböztesse más vállalkozások áruitól vagy szolgáltatásaitól." ${ }^{36}$ Ezt a meghatározást módosította a 2424/2015 Rendelet a következőképpen: „Európai uniós védjegyoltalomban részesülhet minden megjelölés, így különösen szó - beleértve a személyneveket is -, ábra, kép, alakzat, betű, szám, szín, továbbá az áru vagy az áru csomagolásának formája, vagy hang, amely alkalmas arra, hogy:

\footnotetext{
33 Az Európai Parlament És A tANÁCs (EU) 2015/2424/2015 RENDELETE, 2015.

34 AZ Európai Parlament És a TANÁcs (EU) 2017/1001 Rendelete, 2017.

35 A BizotTsÁG (EU) 2018/626 VÉGREHAJTÁsi RENDELETE, 2018.

36 A TANÁCs 207/2009/EK RENDELETE, 2009.
} 
a) valamely vállalkozás áruit vagy szolgáltatásait megkülönböztesse más vállalkozások áruitól vagy szolgáltatásaitól; b) az európai uniós védjegyek lajstromában (a továbbiakban: védjegylajstrom) való ábrázolásának módja lehetôvé tegye azt, hogy az illetékes hatóságok és a nyilvánosság egyértelműen és pontosan meghatározza a jogosultat megillető oltalom tárgyát." ${ }^{37}$. Végül pedig a jelenleg is érvényben lévő 1001/2017-es Rendelet így módosította az európai uniós védjegy meghatározását a II. fejezet, 1. szakasz, 4. cikkében: „Európai uniós védjegyoltalomban részesülhet minden megjelölés, így különösen szó - beleértve a személyneveket is -, ábra, kép, alakzat, betű, szám, szín, továbbá az áru vagy az áru csomagolásának formája, vagy hang, amely alkalmas arra, hogy: a) valamely vállalkozás áruit vagy szolgáltatásait megkülönböztesse más vállalkozások áruitól vagy szolgáltatásaitól; és b) az európai uniós védjegyek lajstromában (a továbbiakban: a védjegylajstrom) való ábrázolásának módja lehetővé tegye azt, hogy az illetékes hatóságok és a nyilvánosság egyértelműen és pontosan meghatározza a jogosultat megillető oltalom tárgyát." 38

A módosítások jelentik a választ azokra a változások által életre keltett kihívásokra, amelyeket az internethez és a digitális világhoz kapcsolódó innovációk idéztek elő. Rámutat erre a 2424/2015-ös módosító Rendelet preambuluma is, amely így fogalmaz a (7) alpontban:

(7) Bár a közösségi védjegyrendszer általános múködésének értékelése megerősítette, hogy a rendszer számos aspektusa, köztük azok az alapvető elvek, amelyekre a rendszer egésze épül, kiállták az idő próbáját, és továbbra is megfelelnek a vállalkozások szükségleteinek és elvárásainak, a Bizottság a szellemitulajdon-jogok egységes piacáról szóló, 2011. május 24-i közleményében arra a következtetésre jutott, hogy korszerúsíteni kell az Unió védjegyrendszerét: egészében véve hatékonyabbá, eredményesebbé, következetesebbé kell tenni és hozzá kell igazítani az internetkorszak követelményeihez. ${ }^{39}$ Hivatalosan is elfogadták, hogy bizonyos védjegyeket lehet csak kizárólagosan elektronikus fájlban megjeleníteni és tárolni, illetve szín komponensû védjegyekre vonatkozó kérelmet nem lehet faxon benyújtani.

37 Az Európai Parlament És A TANÁcs (EU) 2015/2424 Rendelete, 2015.

38 Az Európai Parlament És a Tanács (EU) 2017/1001 Rendelete, 2017.

39 Az Európai Parlament És a TANÁcs (EU) 2015/2424 Rendelete, 2015. 
Jelentős módosítást vezetett be az áruosztályok kiválasztását illetően is a védjegyreform, hiszen a Nizzai osztályozás ${ }^{40}$ alapján pontosan kell kiválasztani a termékeket, szolgáltatásokat, amelyekre a védjegy kérelem vonatkozik, nem lehet beérni csupán általános kategória megnevezésekkel. Ez a módosítás az díjak rendszerét is érinti, mert míg korábban az alapdíj három áruosztályra vonatkozott, most egyetlen áruosztályra vonatkozik. ${ }^{41}$ $\mathrm{Az}$ eljárásrendben az is fontos módosítást jelent, hogy a megszerzett megkülönböztető képességére a védjegynek, már a kérelem benyújtásakor lehet hivatkozni a 626/2018 végrehajtási Rendelet 2 cikk, 2. bekezdése alapján.

A módosításokat több kritika is éri főként arra a vonatkozóan, hogy a különbözô lehetséges védjegy-kategóriákra, védjegyek megjelenítésére vonatkozó előírások nem minden esetben pontosak, vagy vannak összhangban a lehetséges technikai, technológiai megoldásokkal. ${ }^{42} \mathrm{~A}$ rugalmasabb jogszabályi keretek folyamatosan értelmezési kihívások elé állítják mind a védjegybejelentést tevő feleket, mind az Európai Bíróságot, amely esetrôl esetre újraértelmezi és alkalmazza a módosult feltétlen kizáró jellegű kritériumokat. Ennek ellenére a védjegy definíció módosításának szükségességét, illetve a módosítás megalapozottságát senki sem vitatja.

Amint azt Szalai Péter is felvetette egy tanulmányában ${ }^{43}$ továbbra is fennmaradnak fontos megválaszolandó kérdések, mint például az, hogy miként állapítható meg a megkülönböztető képesség kritériumának teljesülése olyan védjegyek esetében, amelyek vizuálisan nem érzékelhetők, vagy a megjelenítés, illetve lajstromban való tárolás, hozzáférhetôség szempontjából hogyan lesz biztosítható a különböző (nem látható) egyedi megjelölések egyedi azonosíthatósága és észlelhetôsége. ${ }^{44}$

\section{A VÉDJEGYREFORM HATÁSA A VÁLLALKOZÁSOK VÉDJEGYVÁLASZTÁSÁRA}

A védjegyek fő funkciói a gazdasági versenyben az alábbiak: megkülönböztető funkció, információközvetítő funkció, reklámfunkció,

\footnotetext{
${ }^{40}$ Forrás: https://www.sztnh.gov.hu/hu/szakmaioldalak/vedjegyoltalom/osztalyozas/nizzai

${ }^{41}$ A BizotTSÁG (EU) 2018/626 VÉGREHAJTÁsi RENDELETE, 2018.

42 SCARMADAGLiA, 2018. 38-58.o., SZALAI, 2017. 343-353.o. és IRIMESCU, 2019. 83-106.o.

43 SZALAI, 2017.353.o.

${ }^{44}$ Uo.
} 
minőségjelző funkció. A védjegy képes a fogyasztó magatartására hatást gyakorolni. ${ }^{45}$ „A jól megválasztott védjegy ugyanis a piacon elónyös pozíciót biz̨tosít a védjegyet használó számára".

A versenyfunkciók érvényesülése azonban nemcsak a védjegy sikeres megformálásától, hanem a megjelölés ismertségétől és a rá fordított beruházásoktól is függ. ${ }^{47}$ Emiatt felmerül a kérdés, hogy vajon a vállalkozások márkaépítési opcióira hatást gyakorolt-e, hogy a védjegyreform megadta a jogszabályi keretet új védjegy-kategóriák lajstromozásához, amelyek jobban tudnak kapcsolódni a digitális innováció, az internet vívmányaihoz? Vagy inkább a vállalkozások továbbra is csak az eddig jól bevált, széleskörben ismert és népszerű szóvédjegy, ábrás védjegy vagy a kettő kombinációjának lehetőségeit kívánják használni, amikor megfelelő jelöléseket keresnek termékeik és/vagy szolgáltatásaik megjelenítésére? Mit választanak, ha céljuk, hogy termékeik különbözzenek a hasonló termékektől, szolgáltatásoktól, könnyen azonosíthatóvá tegyék a termék, szolgáltatás forrását, ugyanakkor pedig ki akarják emelni a terméket és/vagy szolgáltatást a piaci versenyben a „tömegből”, egyedivé, különlegessé címkézve azt a fogyasztók szemében, hogy ez elsődleges vásárlási opciójukat jelentse.

Kérdéses azonban, hogy a piaci versenyben a hagyományos típusú védjegyek képesek-e még olyan hatást gyakorolni a fogyasztóra, mint korábban, illetve tudják-e ugyanazt az ismertséget biztosítani a használó számára, az azonosító funkciót a korábbiakkal hasonló ráfordítások mellett is hasonlóan betölteni, vagy a fogyasztók figyelmét könnyebben felkeltik és vonzzák az új típusú, nem hagyományos védjegyek, mint például a hologram, multimédia, mozgásvédjegy, színvédjegy stb.

Nemrégiben megjelent egy gazdasági vonatkozású tanulmány is, amely azt állítja, hogy az új védjegy-kategóriák bevezetése és az 1001/2017 Rendelet által módosított uniós védjegyrendszer nem segíti a vállalkozásokat a kereskedelmi megjelöléseik jogi oltalom alá helyezésében és azoknak a piaci versenyben való használatában, a vállalkozásoknak csak nagyon kis hányada szeretne élni az új védjegy-kategóriák adta lehetőségekkel. ${ }^{48} \mathrm{~A}$ tanulmány azt emeli ki, hogy 2019 májusában több mint 1,1 millió szóvédjegy-bejelentés volt iktatva az Európai Unió Szellemi Tulajdonjogi

\footnotetext{
45 CSÉCSY, 1998. 162.o.

${ }^{46}$ Uo.

47 TATTAY, 2017. 513.o.

48 PelikánovÁ - MacGregor, 2019. 53-70.o.
} 
Hivatala adatbázisa szerint (ide beletartoznak azok a kérelmek is, amelyek védjegyei sosem lettek lajstromozva, vagy a lejárt védjegyek, amelyeket nem újítottak meg), míg a nem hagyományos védjegy-kategóriákra kevesebb mint 15.000 bejegyzés jelenik meg az adatbázisban. Mindez azt jelenti, hogy az igény a nem hagyományos megjelölések, márkák jogi oltalom alá helyezésére még mindig elenyésző a hagyományos, szóvédjegy, ábrás védjegy, a kettő kombinációjából adódó védjegyek lajstromozására irányuló kérelmekhez képest.

A fenti megállapítás elemzésekor tekintettel kell lenni arra, hogy amennyiben bárki keresést kezdeményez bármilyen típusú védjegyekre vonatkozó kérelmeket illetően az Európai Unió Szellemi Tulajdoni Hivatal védjegyadatbázisában, ${ }^{49}$ ez az adatbázis az adott idôpontban megjeleníthetô összes regisztrált kérelmet kiadja, mint találatot. Ez azt jelenti, hogy ha 2019 májusában kerestek rá azokra a védjegykérelmekre, amelyek szóvédjegyek lajstromozására vonatkoznak, akkor az adott dátumon az adatbázis megjelenítette az összes találatot valamennyi olyan védjegykérelemrôl, amelyeket 2019 májusáig regisztráltak a rendszerben szóvédjegyekként, nemcsak azokat a kérelmeket, amelyeket 2019-ben jegyeztek be. Nyilvánvalóan, ha ezt a bontást nézzük, akkor sokkal kevesebb védjegyet regisztrálhattak például mozgásvédjegyre, hologramra vagy multimédiára, amelyek bejegyzését tulajdonképpen külön védjegy-kategóriaként a 1001/2017 Rendelet alkalmazása tette lehetségessé, mint szóvédjegyre vagy ábrás védjegyre, amelyek lajstromozása lehetséges volt 1996-tól, amikor a Belső Piaci Harmonizációs Hivatal (mai nevén Európai Unió Szellemi Tulajdoni Hivatala) megkezdte működését.

Éppen ezért nem érdemes levonni azt a következtetést, hogy a vállalkozások nem érdeklődnek az új védjegy-kategóriák, lajstromozási lehetőségek iránt, amelyeket az 1001/2017 Rendelet lehetővé tett, arra hivatkozva, hogy sokkal kisebb arányban nyújtottak be eddig lajstromozási kérelmet nem hagyományos védjegyekre, mint hagyományos védjegyekre. Ugyanis a hagyományos védjegyek jogi oltalom alá helyezésére sokkal hosszabb idő állt rendelkezésre, mint az új védjegy-kategóriák esetében, ahol a lajstromozási lehetőség csak néhány éve jelent meg, külön nevesítve az 1001/2017 Rendelet 4. cikkében vagy az abszolút kizáró lajstromozási feltételek előírásaira alapozva.

${ }^{49}$ Forrás: https://www.tmdn.org/tmview/welcome, https://euipo.europa.eu/eSearch/ 
Ahhoz, hogy pontosabb képet kapjunk arról, hogy valóban hatással van-e a védjegyreform által bevezetett új védjegy-kategóriák lajstromozási lehetősége a vállalkozások választásaira, döntéseire a kereskedelmi versenyben használni kívánt védjegyekre vonatkozóan, azt is meg kell néznünk, hogy 2016 óta - amikor hatályba lépett a 2424/2015 Rendelet a közösségi védjegyrôl szóló 207/2009/EK tanácsi rendelet és a közösségi védjegyről szóló 40/94/EK tanácsi rendelet végrehajtásáról szóló 2868/95/EK bizottsági rendelet módosításáról, valamint a Belső Piaci Harmonizációs Hivatalnak (védjegyek és formatervezési minták) fizetendő díjakról szóló 2869/95/EK bizottsági rendelet hatályon kívül helyezéséről hogyan alakult a különböző nem hagyományos védjegyekre benyújtott kérelmek száma.

A módosításokat jól megalapozott vizsgálat előzte meg, amelyet a Max Planck Szellemi Tulajdonjogi és Versenyjogi Intézet végzett az Európai Bizottság felkérésére. A tanulmány végkövetkeztetése pedig az, hogy a védjegyrendszer módosítását elsősorban az tette szükségessé, hogy a védjegyek lajstromozásának a grafikai ábrázolhatóság feltétele elavult, gátat szabott egyes új típusú megjelölések oltalmazásának. ${ }^{50}$

A 2424/2015 Rendelet preambuluma a következőképpen fogalmaz a változások bevezetésének szükségességéről:

(7) „Bár a közösségi védjegyrendszer általános működésének értékelése megerősítette, hogy a rendszer számos aspektusa, köztük azok az alapvető elvek, amelyekre a rendszer egésze épül, kiállták az idő próbáját, és továbbra is megfelelnek a vállalkozások szükségleteinek és elvárásainak, a Bizottság a szellemi tulajdonjogok egységes piacáról szóló, 2011. május 24-ei közleményében arra a következtetésre jutott, hogy korszerúsíteni kell az Unió védjegyrendszerét: egészében véve hatékonyabbá, eredményesebbé, következetesebbé kell tenni és hozzá kell igazítani az internetkorszak követelményeihez.

(9) Annak érdekében, hogy a jogbiztonság növelésével egyidejűleg nagyobb rugalmasságot tegyünk lehetővé a védjegyek ábrázolási módja tekintetében, a grafikai ábrázolhatóság követelményét törölni kell az európai uniós védjegy fogalom meghatározásából. A megjelölés bármely megfelelő formában - azaz nem szükségszerűen grafikai eszközökkel -, széles körben elérhető technológia alkalmazásával történő ábrázolásának megengedettnek

50 SZALAI, 2017. 351.o. 
kell lennie, amennyiben az ábrázolás egyértelmű, pontos, önmagában teljes, könnyen hozzáférhetô, érthető, tartós és objektív". ${ }^{51}$

Amennyiben megvizsgáljuk az EUIPO adatbázisát, összesen 512.275 kérelmet nyújtottak be uniós védjegyekre 2016. január 1. és 2020. március 31. között.

Azért ezt az idôszakot vizsgáljuk, mivel a védjegyreform szempontjából ez az időszak tekinthető relevánsnak, hiszen már tudjuk, hogy elindult egy folyamat a 207/2009 Rendelet módosításával: a 2424/2015 Rendelet 2016. március 23-tól, míg a 1001/2017 Rendelet amely tételesen kimondja, hogy a grafikai ábrázolhatósághoz való kötöttség többé már nem kizáró abszolút lajstromozási feltétel - 2017 októberétől lépett hatályba.

Ezek közül a védjegybejelentések közül 1789 térbeli védjegy, 114 színvédjegy, 83 mozgás védjegy, 3 hologram védjegy, 41 multimédia védjegy, 190 olyan védjegy, amely a „más”-ként meghatározott védjegyek kategóriájába esik, 61 mintavédjegy, 173 pozíció védjegy, 117 hangvédjegy, 270866 szóvédjegy, 238838 figuratív védjegy. ${ }^{52}$

A fenti adatokból látszik, hogy sokkal nagyobb arányban igényelnek a vállalkozások hagyományos típusú védjegyeket, mint nem hagyományos típusú védjegyeket. Ugyanakkor azt is fontos észrevenni, hogy az összes 2571 nem hagyományos típusú védjegyből 190 a „más védjegyek” kategóriájába került, ami azt mutatja, hogy létezik számos olyan kereskedelmi megjelölés, amelyek nem hagyományosak, hanem kreatívak és innovatívak, és a meglévő meghatározott védjegykategóriákba nem illeszthetők be, mivel nem létezik még pontos technikai, jogi leírás a jelölésükre. Mindez azt jelzi, hogy elindult egy változás a tekintetben, hogy hogyan látják a vállalkozások a védjegyet, valamint, hogy mit gondolnak arról, hogy milyen típusú megjelölések lennének képesek a legjobban betölteni a védjegynek azt a funkcióját, hogy a terméket vagy szolgáltatást megkülönböztessék más hasonló termékektől vagy szolgáltatásoktól és azonosítsák a termék vagy szolgáltatás eredetét, amely által képesek kiváltani a fogyasztók érdeklődését és tartósan megőrizni azt, vagyis kialakítani a fogyasztók lojalitását.

A nem hagyományos védjegyek bejelentésére vonatkozó kérelmek megoszlása típusonként és évenként a vizsgált időszakban:

51 Az Európai Parlament És A TANÁcs (EU) 2015/2424 Rendelete, 2015.

${ }^{52}$ Forrás: https://euipo.europa.eu/eSearch/\#advanced/trademarks 
1. térbeli védjegy

2016. január 1. és 2017. január 1. - 445

2017. január 1. és 2018. január 1. - 407

2018. január 1. és 2019. január 1. - 455

2019. január 1. és 2020. március 31. - 482

2. színvédjegy

2016. január 1. és 2017. január 1. - 19

2017. január 1. és 2019 január 1. - 30

2018. január 1. és 2019. január 1. - 29

2019. január 1. és 2020. március 31. - 36

3. hologram védjegy

2016. január 1. és 2017. január 1. - 0

2017. január 1. - 2018. január 1. - 1

2018. január 1. és 2019. január 1. - 1

2019. január 1. és 2020. március 31. - 1

4. mozgás védjegy

2016. január 1. és 2017. január 1. - 0

2017. január 1. - 2018. január 1. - 10

2018. január 1. és 2019. január 1. - 33

2019. január 1. és 2020. március 31. - 40

5. multimédia védjegy

2016. január 1. és 2017. január 1. - 0

2017. január 1. - 2018. január 1. - 5

2018. január 1. - 2019. január 1. - 15

2019. január 1. és 2020. március 31. - 21

6. „más” védjegy (egyéb kategória)

2016. január 1. és 2017. január 1. - 207

2017. január 1. - 2018. január 1. - 39

2018. január 1. - 2019. január 1. - 12

2019. január 1. és 2020. március 31. - 32

7. minta védjegy

2016. január 1. és 2017. január 1. - 0

2017. január 1. - 2018. január 1. - 8

2018. január 1. - 2019. január 1. - 22

2019. január 1. és 2020. március 31. - 31

8. pozíció védjegy

2016. január 1. és 2017. január 1. - 0 pozíció

2017. január 1. - 2018. január 1. - 20 pozíció 
Az európai uniós védjegy (EUTM) kizáró lajstromozási kritériumai módosulásának hatása a vállalkozások védjegyválasztására

2018. január 1. - 2019. január 1. - 55 pozíció

2019. január 1. és 2020. március 31. - 98 pozíció

9. hang védjegy

2016. január 1. és 2017. január 1. - 15

2017. január 1. - 2018. január 1. - 22

2018. január 1. - 2019. január 1. - 23

2019. január 1. és 2020. március 31. - 57

Olfaktorikus védjegyre vonatkozó lajstromozási bejelentés a vizsgált időszakban nem nyújtottak be. ${ }^{53}$

A nem hagyományos, Európai Szellemi Tulajdoni Hivatalához benyújtott védjegybejelentések a vizsgált időszakban a fenti felbontás szerint árnyaltabb képet mutatnak a védjegyreform és a vállalkozások márkaépítésének, az új típusú védjegyek iránti igényének összefüggéseiről az ESearch plus adatbázis adatai alapján, ${ }^{54}$ mivel kimutatható, hogy az egyes védjegy-kategóriákat illetôen a benyújtott kérelmet száma hogyan módosult évenként, beleértve a nem hagyományos védjegyek kategóriáit is, különkülön. Tekintve, hogy a 2424/2015 Rendelet 2016. március 23-tól, míg a 1001/2017 Rendelet 2017. október 1-jétől hatályos, megállapítható, hogy a védjegyreform hatására a nem hagyományos típusú védjegyek bejelentésének száma, körülbelül állandó évenként. Ezzel szemben például a térbeli védjegyek száma folyamatosan növekvő tendenciát mutat, hasonlóan a pozíció vagy multimédia védjegyekhez.

Érdekes megfigyelni azt is, hogy a „más” védjegy-kategóriába eső bejelentések száma viszont csökkent, ugyanis míg a 2016. január 1. - 2017. január 1. időszakban 207 bejelentés volt, addig a 2019. január 1. - 2020. március 31. időszakban mindössze 32 volt, annak ellenére, hogy összességében véve a nem hagyományos típusú védjegyekre irányuló védjegybejelentések száma nőtt a vizsgált időszakban. Mindez azt mutatja, hogy ezeket a védjegyeket a védjegyreform hatására különböző kategóriákba kezdték besorolni. Egyre inkább megtalálták a „más” védjegyek megfelelő

\footnotetext{
${ }^{3}$ Illatvédjegyet akkor lehet bejegyeztetni, ha maga az illat a terméknek amelyhez tartozik nem sajátja, vagy lényeges különbözik a termék tulajdonságaihoz tartozó illattól. A kritérium alapján a"frissen vágott fü illatát" az OHIM teniszlabdákra engedélyezte, OHIM, R 156/1998. Ezt a sikeresen oltalom alá helyezett illatvédjegyet ismeri az európai uniós joggyakorlat.

${ }^{54}$ Forrás: https://euipo.europa.eu/eSearch/\#advanced/trademarks
} 
helyét a lajstromozási kategóriában, míg korábban ez nem volt lehetséges, úgymond ez a „más” volt a védjegy-kategóriák szemetese, ahová minden belefért, amire nem volt megfelelő elhelyezési előírás.

\section{KONKLÚZIÓ}

A fentiek alapján kijelenthető, hogy a védjegyreform hatással van arra, hogy a vállalkozások mit gondolnak a védjegyekről, milyen védjegyeket alkotnak. Ennek következtében egyre inkább igénybe veszik a védjegyreform adta lehetôségeket, hogy új típusú, innovatív, kreatív védjegyekre tegyenek bejelentést, és azokat használják a piaci versenyben kereskedelmi céljaik megvalósítására. Összefüggés mutatható ki a nem hagyományos kategóriájú védjegyek számának növekedése és a védjegyreform által bevezetett, az abszolút kizáró lajstromozási kritériumok módosítása között. A vállalkozások „meglátták” a lehetőséget, amely a lajstromozási eljárásban nyílt, így inkább próbálkoznak újszerű, innovatív védjegyek lajstromozásával. Ugyanis kiszámíthatóbbá vált az Európai Unió Szellemi Tulajdoni Hivatalának az eljárása: (rugalmasan elemzi ezeket a bejelentéseket) továbbá az Európai Bíróság is rugalmas joggyakorlatot igyekszik kialakítani ebben a kérdésben, így nagyobb az esélye az új védjegykategóriákba illő európai uniós védjegyek lajstromozási sikerének.

Ezenkívül az Európai Bizottság 2018-as évi beszámolójában ${ }^{55}$ az intellektuális jogok védelmére vonatkozóan azt állapította meg, hogy az Európai Unió határainál elkövetett jogsértések javarésze az intellektuális jogok területén az uniós védjegyek ellen irányult. Vagyis a vámhatóságok által elkobzott árura elsősorban a védjegyhamisitás volt jellemző, és a hamisított védjegyek 64,5\%-a európai uniós védjegy volt. Ennek alapján viszont feltételezhető, hogy a vállalkozások, amelyek részt vesznek az Európai Unió versenypiacán egyre inkább motiváltabbak abban, hogy megtalálják a termékeik, szolgáltatásaik számára azt a megfelelő megjelölési formát, amely jogi oltalom alá helyezhető az egységes jogi oltalmat biztosító Európai Unió Szellemi Tulajdoni Hivatalánál, ugyanakkor kellően eltér a megszokottól ahhoz, hogy felhívja a fogyasztók figyelmét.

Kutatások szerint a piaci versenyben léteznek szellemi tulajdon intenzív ágazatok (bortermelés, a testápolási cikkek, a játék- és

55 REPORT ON THE EU CUSTOMS ENFORCEMENT OF INTELLECTUAL PROPERTY RIGHTS: RESULTS AT THE EU BORDER, 2018. 
sportszergyártás, valamint a honlapok szolgáltatása), vagyis olyan ipari ágazatok, ahol különösen fontos, hogy a létrehozott termékek, szolgáltatások jogi oltalom alá legyenek helyezve, mivel enélkül tulajdonképpen nem létezhetnek a piacon, nem versenyképesek. ${ }^{56}$ Ennek kapcsán érdemes megjegyeznünk, hogy további kutatások tárgyául szolgálhat az, hogy vajon a szellemi tulajdonjog intenzív ágazatok vállalkozásai nagyobb érdeklődéssel fordulnak-e a nem hagyományos védjegy-kategóriák felé és igyekeznek-e nagyobb mértékben használni azokat, annak érdekében, hogy kitűnjenek a piacon és fokozzák versenyképességüket, vagy ezzel szemben továbbra is a hagyományos védjegy-kategóriákba tartozó védjegyekre építenek az értékesítésben és ezek bejelentését, lajstromoztatását részesítik előnyben.

Azt is figyelembe kell vennünk, amikor a védjegyreform hatását vizsgáljuk a vállalkozások márkaépítési irányaira, hogy ez szoros összefüggésben áll az Európai Bíróság joggyakorlatával, maga a védjegyreform pedig egy komplex folyamat, amelyet az Európai Bíróság joggyakorlata határozott meg. Az Európai Bíróság védjegyjogi gyakorlatának legtöbbször a védjegyek megkülönböztető képessége áll a középpontjában. Az Európai Bíróság úgy foglalt állást, hogy a védjegyek megkülönböztető képességének nem feltétele sem az egyedi, sem az eredeti jelleg. Még ha az egyedi, illetve eredeti sajátosságok megléte nem is képezi a lajstromozás conditio sine qua non-ját, meglétük biztosíthatja a védjegynek a megkülönböztetô képesség előírt szintjét. A védjegy jogi oltalom alá helyezhetôségéhez az szükséges, hogy lényegét tekintve eltérjen az érintett termékek kereskedelemben szokásosan használt megjelöléseitől. ${ }^{57}$

Az Európai Bíróság joggyakorlatában a védjegyreformot megelőzően is számos nem hagyományos típusú védjegy szerepelt, amelyeknek megkülönböztetô képességét elemezte, és ha úgy találta, hogy a védjegy megfelel a grafikai ábrázolhatóság kritériumainak, például a mozgást

\footnotetext{
56 TATTAY, 2017. 506.o.

57 SZALAI, 2015. 132.o.
}

Például a Novartis AG vs. EUIPO T-678/15 ügyben, az EUIPO úgy itélte meg, hogy a grafikai jel csupán egy egyszerűsített ábrázolása egy ovális alakú gyógyszer tablettának, míg az Európai Bíróság végül úgy döntött, hogy jogi oltalom alá helyezhető, mert egy emelkedő „C” betűt formáz és a holdra utal, így megkülönböztető képességgel rendelkezik. Egy térbeli védjegyre vonatkozó ügyben - Coca-Cola Company vs. OHIM T-411/14 viszont az Európai Bíróság nem hagyta jóvá a védjegykérelem bejegyzését, arra hivatkozva, hogy a palack formája, amelyre a kérelem vonatkozott, semmiben sem különbözik a kereskedelemben szokványosan használatos hasonló palackoktól. 
állóképek sorozatával ábrázolták, fényjelzés vagy hologram megfelelően ábrázolt kétdimenziós képen, a hang nemcsak egyszerűen lekottázott, hanem tartalmazza az összes ütemet, előjegyzést, ütemeket, zenei hangokat, szünetjeleket is tartalmaz, (és nem ütközik a védjegybejelentés más feltétlen kizáró lajstromozási kritériumokba) akkor jóváhagyta a nem hagyományos védjegyek lajstromozását is. ${ }^{58}$

A 2016. január 1. - 2020. március 31. közötti időszakban bejelentett, nem hagyományos uniós védjegyek adatainak vizsgálata azt erősíti meg, hogy bár továbbra is a meghatározó irány a védjegy-kategóriák választásában a hagyományos, szó-és ábrás védjegyek, illetve ezek kombinációja, de a vállalkozások egyre növekvő érdeklődéssel fordulnak az innovációhoz köthető újszerű, nem hagyományos védjegykategóriák felé, hogy megkülönböztető megjelöléseiket jogi oltalom alá helyezzék. Arra következtethetünk tehát, hogy a jogszabályi keret rugalmasabbá válása az 1001/2017 Rendelet által azt közvetíti a vállalkozások felé, hogy éljenek gyakrabban a nem hagyományos védjegy-kategóriák használatával is, mivel a jogszabályi módosításoknak és az Európai Bíróság egységre törekvő joggyakorlatának köszönhetően a lajstromozási folyamat egyre kiszámíthatóbb. Ez a megállapítás még akkor is helytálló, ha a megjelölések megjelenítési eszközeinek technológiai variációs lehetőségei, vagy éppen azok hiánya sokszor kihívások elé állítják a vállalkozásokat, az Európai Bíróságot és az Európai Unió Szellemi Tulajdoni Hivatalát egyaránt.

Összességében véve tehát azt mondhatjuk, hogy a védjegyreform hatással van a vállalkozások márkaépítésének irányára, a vállalkozások

58 Például a 005170113 hangvédjegy esetében, amelyre a Metro - Goldwin-Mayer Lion Corporation nyújtott be kérelmet 2006-ban, a védjegy megjelenítésénél a hangfrekvenciák ábrája látható, mivel egy 2.5 másodperces oroszlánüvöltésre vonatkozik, a lajstromozás pedig azért vált lehetségessé mert a leírásban feltüntették az összes időtávot, frekvenciákat, a hang frekvenciáinak pontos váltakozását és azt is, hogy mi érzékelhető. Még 1996-ban nyújtottak be kérelmet fényjelzés levédésére, amelyet 2001-ben sikerült jogi oltalom alá helyezni 000013359 https://euipo.europa.eu/eSearch/\#details/trademarks/000013359, úgy hogy a leírásban zöld és sárga színek használata szerepel eladási felületen. Az Eve Holding Inc. háromdimenziós hologram védjegyre vonatkozó kérelmét 2002-ből úgy jegyezték be, hogy a hologram megjelenítése kétdimenziós, szaggatott vonalakkal érzékeltetve a háromdimenziós ábra megjelenítését, a leírás pedig tartalmazza, hogy a holografikus papír párhuzamos vonalakban jeleníti meg a holografikus színspektrumot. 2000-ben a 001864610 mozgóvédjegyet állóképek sorozatával jelenítették meg, és így lajstromozták.

Forrás:

https://euipo.europa.eu/eSearch/\#basic/1+1+1+1/100+100+100+100/001864610 
védjegyválasztására, továbbá az abszolút kizáró lajstromozási feltételekre vonatkozóan összefüggés mutatható ki a nem hagyományos, újszerü védjegybejelentések számának növekedése és az 1001/2017 Rendelet rugalmasabb előírásai között.

\section{FELHASZNÁLT IRODALOM}

A BizotTSÁg (EU) 2018/626 VÉGREHAJTÁSI RENDELETE (2018). Elérhető: https://eur-lex.europa.eu/legal-

content/HU/TXT/HTML/?uri=CELEX:32018R0626\&from=EN

(Letöltve: 2020.05.04)

A TANÁCS 207/2009/EK RENDELETE (2009). Elérhető: https://eurlex.europa.eu/legal-

content/HU/TXT/HTML/?uri=CELEX:32009R0207\&from=EN

(Letöltve: 2020.05.04)

A TANÁCS ELSŐ IRÁNYELVE A VÉDJEGYEKRE VONATKOZÓ TAGÁLLAMI SZABÁLYOK KÖZELÍTÉSÉRŐL (1988). Elérhető: https://eurlex.europa.eu/legal-

content/HU/TXT/HTML/?uri=CELEX:31989L0104\&from=HU (Letöltve: 2020.05.04)

Adams, Mitchell, Scardamaglia Amanda (2018): Non-Traditional Trademarks, The protection of non-traditional trademarks.Critical perspectives, Oxford University Press. DOI azonosító: 10.1093/oso/9780198826576.001.0001

Az EuRÓPAi PARLAMENT ÉS A TANÁCS (EU) 2015/2424/2015 RENDELETE (2015). Elérhető: $\quad \underline{\text { https://eur-lex.europa.eu/legal- }}$ content/HU/TXT/HTML/?uri=CELEX:32015R2424\&from=EN

(Letöltve: 2020.05.04)

Az Európai Parlament És a TANÁCs (EU) 2017/1001 RENDELETE (2017). Elérhető: https://eur-lex.europa.eu/legalcontent/HU/TXT/PDF/?uri=CELEX:32017R1001\&from=NL (Letöltve: 2020.05.04)

BABBIE, EARL (2003): A társadalomtudományi kutatás gyakorlata, Budapest, Ballasi Kiadó, hatodik átdolgozott kiadás

C-49/02 - Heidelberger Bauchemie (2004). Elérhető: http://curia.europa.eu/juris/liste.jsf?num=C-49/02 (Letöltve: 2020.05.04) 
C-273/00 - SIECKMANN (2002). Elérhető:

http://curia.europa.eu/juris/liste.jsf?language $=$ hu\&jur $=C, T, F \&$ num $=c-$ 273/00\&td=ALL (Letöltve: 2020.05.04)

C-283/01 - SHIELD MARK (2003). Elérhető:

http://curia.europa.eu/juris/liste.jsf?num=C-283/01 (Letöltve: 2020.05.04)

C-353/03 - NESTLÉ (2005). Elérhető: http://curia.europa.eu/juris/liste.jsf?num=C-353/03 $\quad$ (Letöltve: 2020.05.04)

CSÉCSY GYÖRGY (1998): A szellemi alkotások joga, Miskolc, Novotni Kiadó EUIPO ANNUAL REPORT (2018), European Union Intellectual Property Office. Elérhetô: https://euipo.europa.eu/tunnelweb/secure/webdav/guest/document library/contentPdfs/about euip o/annual report/annual report 2018 en.pdf (Letöltve: 2020.05.04)

EUIPO Facts and Figures Report 2016 (2017), European Union Intellectual Property Office. Elérhető: https://euipo.europa.eu/tunnel$\mathrm{web} /$ secure/webdav/guest/document library/contentPdfs/about euip o/annual report/ar 2016 annex 07 en.pdf (Letöltve: 2020.05.04)

EURÓPA 2020 STRATÉGIA (2010), Európai Bizottság. Elérhető: https://eurlex.europa.eu/legalcontent/HU/TXT/HTML/?uri=CELEX:52010DC2020\&from=HU (Letöltve: 2020.05.04)

HORIZON 2020 rövid bemutatása (2014). Elérhető:

https://ec.europa.eu/programmes/horizon2020/sites/horizon2020/file s/H2020 HU KI0213413HUN.pdf (Letöltve: 2020.05.04)

IRIMESCU, GEORGE MiHAi (2019): Protecția mărcilor netradiționale, în special a mărcilor multimedia, Revista Română de Dreptul Proprietății Intelectuale, 2.szám. https://www.ceeol.com/search/articledetail?id $=791516$

KOVÁTS BORBÁLA LILI (2017) Grafikai ábrázolhatóság az Európai Uniós védjegyjogban, Iparjogvédelmi és Szerzői Jogi Szemle, 122. évfolyam. 6. szám: https://www.sztnh.gov.hu/hu/szerzoi-jogi-szemle/szemle-201706

MACGregor, RAdKA., MACGregor, KENYON (2019): The impact of the new EU

trademark regime on entrepreneurial competitiveness, Forum Scientiae Oeconomia, 2.vol. https://www.ceeol.com/search/articledetail?id $=786296$ 
Az európai uniós védjegy (EUTM) kizáró lajstromozási kritériumai módosulásának hatása a vállalkozások védjegyválasztására

MADRIDI JEGYZŐKÖNYV (2017), World Intellectual Property Organization (WIPO). Elérhető: https://wipolex.wipo.int/en/text/283483 (Letöltve: 2020.05.04)

MADRIDI MEgÁLLAPODÁs (1979). Elérhető: https://www.sztnh.gov.hu/hu/a-vedjegyek-nemzetkozi-lajstromozasara1891-aprilis-14-en-kotott-stockholmban-1967-julius-14-en (Letöltve: 2020.05.04)

PelikÁnOVÁ, Radka MacGregor - MacGregor, Robert KenYon (2019): The impact of the new EU trademark regime on entrepreneurial competitiveness, Forum Scientiase Oeconomia, 7/2019. No. 2.

REPORT ON THE EU CUSTOMS ENFORCEMENT OF INTELLECTUAL PROPERTY RIGHTS: RESUlTS AT THE EU BORDER (2018), European Commission : https://ec.europa.eu/taxation customs/sites/taxation/files/2019-iprreport.pdf

SZALAI PÉTER (2015): A megkülönböztetőképesség jelentése a védjegyjogban, Győr, Universitas-Győr Nonprofit Kft: https://dfkonline.sze.hu/images/egyedi/monogr $\% \mathrm{C} 3 \% \mathrm{~A} 1 \mathrm{fi} \% \mathrm{C} 3 \% \mathrm{~A} 1 \mathrm{k} /$ Szalai Pet er.pdf

SZALAI PÉTER (2017): A védjegy fogalmának változása az Európai Unióban., Acta Universitatis Sapientiae, Legal Studies 2.vol: https: / www.ceeol.com/search/article-detail $\mathrm{id}=600725$

T-3/15 - K-SwISS V OHIM (2015). Elérhetô: http://curia.europa.eu/juris/liste.jsf?language $=$ en\&num $=\mathrm{T}-3 / 15$ (Letöltve: 2020.05.04)

T - 143/14 (2015). Elérhető: http://curia.europa.eu/juris/liste.jsf?num=T143/14\&language $=\mathrm{EN}$ (Letöltve: 2020.05 .04 )

T-411/14 - COCA-COLA VS. OHIM. Elérhetô: http://curia.europa.eu/juris/liste.jsf?num=T-411/14 (Letöltve: 2020.05.04)

C-433/17 P - ENERCON vs EUIPO (2018). Elérhető: http://curia.europa.eu/juris/liste.jsf?language $=$ en\&num $=\mathrm{C}$ 433/17\%20P (Letöltve: 2020.05.04)

Tattay LEVENTE (1995): A VÉDJEgY ÉS A VÁLLALKOZÁSOK ARCULATA, MARKETING \& Management, 5.szám

TATTAY LEVENTE (2017): Versenyképesség és szellemi alkotások az Európai Unióban, Wolters Kluwer Kft, e-book 